\title{
Production of Healthy Chips Ready to Eat Using Potato, Green Pea and Lupine Flour for Malnourished Children
}

\author{
Maha I. K. Ali ${ }^{1}$, Esraa A. M. Mousa ${ }^{1}$, Naglaa A. A. Hassan ${ }^{2}$ \\ ${ }^{1}$ Department of Special Food and Nutrition, Food Technology Research Institute, Agricultural Research Center, Giza, Egypt \\ ${ }^{2}$ Department of Home Economics, Faculty of Agriculture, Alexandria University, Alexandria, Egypt
}

Email address:

mahaik82@yahoo.com (M. I. K. Ali), esraa_am228@yahoo.com (E. A. M. Mousa), naglaa29172@gmail.com (N. A. A. Hassan)

\section{To cite this article:}

Maha I. K. Ali, Esraa A. M. Mousa, Naglaa A. A. Hassan. Production of Healthy Chips Ready to Eat Using Potato, Green Pea and Lupine Flour for Malnourished Children. International Journal of Food Science and Biotechnology. Vol. 4, No. 1, 2019, pp. $26-34$.

doi: $10.11648 /$ j.ijfsb.20190401.14

Received: February 25, 2019; Accepted: April 4, 2019; Published: May 6, 2019

\begin{abstract}
Potato chips are the most popular snack consumed especially by children. These chips are considered unhealthy due to high levels of fat and salt content. This study was conducted to produce healthy chips from potato, lupine and green pea flour and enhance the nutritional value of chips. The chips were prepared using Potato, lupine and green pea flour at different ratios (100\%:0\%:0\%, 90\%:10\%:0\%, 85\%:15\%:0\%, 90\%:0\%:10\%, 85\%:0\%:15\%, 80\%:10\%:10\% and 70\%:15\%:15\% respectively). Proximate analysis, minerals content, amino acids composition, physicochemical analysis, biological active compounds analysis and sensory evaluation were carried out on the product chips samples. It showed that moisture content ranged between (7.43-8.77), protein content (7.89-16.07), crude ether extract content (3.90-6.31), ash content (3.00-3.75), crude fiber (2.75-4.12) and carbohydrate content (74.77-61.66). The Minerals analysis revealed that sample G (70\% potato flour and $15 \%$ lupine flour and $15 \%$ green pea flour) was the highest in potassium, iron, calcium and zinc content with low sodium content. The amino acids composition was found that the sample G contained the highest percentage of the essential amino acids including (lysine, phenylalanine threonine and valine). Physicochemical analysis revealed the following ranges: bulk density $(0.74-0.91 \mathrm{~g} / \mathrm{ml})$, water absorption $(1.70-1.94 \mathrm{~g} / \mathrm{g})$, swelling capacity $(1.12-1.95 \mathrm{ml} / \mathrm{g})$ and $\mathrm{pH}(5.44-5.89)$. Biological active compounds analysis reported the following ranges $(\mathrm{mg} / 100 \mathrm{~g})$ : total phenolic content $(790.84-1783.64)$ and antioxidant activity (82.78\%-97.16\%). While, sensory evaluation results showed that no significant difference between the products of the seven chips samples. Conclusively healthy chips can be prepared successfully from each potato, green Pea as well as lupine Flour as a nutritious snack to children suffering from malnutrition.
\end{abstract}

Keywords: Healthy Chips, Lupine, Green Pea, Amino Acids, Minerals, Antioxidant Activity, Malnutrition

\section{Introduction}

Malnutrition is one of the most common problems among developing countries, with more than 800 million children under 5 years old suffering from malnutrition and weakly growth. Whereas more than 10 million deaths per year in that age $[1,2]$.

Potato chips are the most popular snack consumed in people especially by children [3]. Nevertheless, these chips are considered unhealthy because they contain high levels of fat and salt, as well as acrylamide which is formed at high temperatures [4-6], aldehydes, ketones and trans fatty acids $[7,8]$.
However, because of its favorable taste as the addition of mono sodium glutamate these chips are constantly consumed in social occasions as a snack, they are also eaten during the day, [9].

Healthy Snacks must be containing all nutrients, should provide energy and easy to eat as well as palatable taste. Finally, must be considered to be healthy [10].

Potatoes (Solanum tuberosum) is one of the most important crops in the world in addition to wheat, rice and corn [11]. Also it considered as good source of carbohydrates, proteins, which contain amino acids that fulfilled human requirements, phosphorus, iron, calcium, vitamin $\mathrm{C}, \mathrm{B} 1$ and $\mathrm{B} 2$, and has high protein calorie ratio ([12]. Potato also contains antioxidants as phenolic acids, 
ascorbic acid and carotenoids [13]. So, we can benefit from the high nutritional value of potatoes in reducing malnutrition among children.

Peas (Pisum sativum) is an herbaceous vine belonging to the leguminosae family also it considered to be one of the cheapest crops and the highest nutritional value and also processed seeds are used to preparation of functional foods especially for pre-school children to improve the utilization of protein. Furthermore, green pea protein is rich in lysine whereas mostly cereal proteins are lacking in lysine so can complement cereals complying with pea protein [14].

FRIAS et al. [15] found that reported negligible trypsin inhibitor activity in pea during extrusion process at $129^{\circ} \mathrm{C}$, $135^{\circ} \mathrm{C}$, and $142^{\circ} \mathrm{C}$. Which indicated that these temperatures considered, suitable for the manufacturing of novel peaderived products which characterized by high nutritional value and natural green color [16].

Lupine (Lupinus) flour is a new food ingredient. Which is rich in $40-45 \%$ protein, $25-30 \%$ fiber, nutritionists have been recommended increasing consumption of dietary fiber in daily diet to improve health. Fiber is also important to reduce the risk of cardiovascular diseases, diabetes, obesity and certain types of cancers [17]. It was found to be reliable source of antioxidants which consist of the polyphenolic compounds and flavonoids [18, 19]. Compared to soybeans and other legumes, Lupine contains a small amount of anti-nutrition. Also it has great importance in incorporation with a wide range of several foods such as cereal products due to its pale in color and low in odor and flavor [20, 21, 22].

Thus, the aim of the study is to produce healthy chips ready to eat using Potato, Green Pea and Lupine Flour for malnourished children.

\section{Materials and Methods}

\subsection{Materials}

Potatoes (Solanum tuberosum L., var. cara), dried green peas (DGP), sweet lupine seeds, sugar, salt, whey powder, spices (black pepper, garlic powder and onion powder; $1: 1: 1)$, corn oil were obtained from the local market, Alexandria, Egypt. The lupine and dried green peas were milled using a hummer mill 1400 perten) and passed through a $10 \mathrm{~mm}$ sieve. All chemicals and reagents used in this study were of analytical grade.

\subsection{Methods}

\subsubsection{Preparation of Potato Flour}

The chosen potatoes do not contain any infection or infestation and then washed with running tap water to remove any soil, dirt and dust and then put them in vessel of boiling water for 15-20 minutes, then peeling and Shredding them using a stainless steel milling, then placing the samples in drying trays in a single layer and placed in the drying oven at $55^{\circ} \mathrm{C}$ for 24 hours, Finally, dried potato samples are milling with an electric mill [23].

\subsubsection{Production of Healthy Chips}

The healthy chips as shown in table 1 . were prepared by mixing potato flour, lupine, green peas, and other ingredients, including (salt, sugar, spices (black pepper, garlic powder and onion powder, 1:1:1), corn oil, whey powder and water) according to the method described by Adedapo et al. [10]. All ingredients were mixed until we get smooth dough, $10 \mathrm{~min}$ resting of dough, then shredding the dough and forming it, then baked in the electric oven at $180^{\circ} \mathrm{C}$ for 12 minutes, then cooled, packaged and labeled.

Table 1. Ingredients used for production of healthy chips.

\begin{tabular}{lllllll}
\hline \multirow{2}{*}{ Ingredients } & Samples & & & & \\
\cline { 2 - 6 } & A & B & C & D & E & G \\
\hline Potato flour (\%) & 100 & 90 & 85 & 90 & 85 & 70 \\
Lupine flour (\%) & 0 & 10 & 15 & 0 & 10 & 15 \\
Green pea flour (\%) & 0 & 0 & 0 & 3 & 3 & 10 \\
Salt (g) & 3 & 3 & 2 & 2 & 3 & 2 \\
Sugar (g) & 2 & 2 & 3 & 3 & 3 & 3 \\
Corn Oil (g) & 3 & 3 & 3 & 3 & 3 & 3 \\
Spices mixture (g) & 3 & 3 & 3 & 3 & 3 \\
Whey powder (g) & 3 & & & 3 & 3 \\
\hline
\end{tabular}

\subsubsection{Proximate Chemical Composition}

Proximate chemical composition including moisture, crude ether extract, crude protein $(\mathrm{N} \times 6.25)$, crude fiber and total ash were determined according to the AOAC [24]. Total carbohydrate was calculated by difference. Total calories were calculated as mentioned by Zambrano et al., [25] according to the following equation

Total calories $=4($ protein + Carbohydrates $)+9($ fat $)$

\subsubsection{Determination of Minerals}

Minerals (Iron, Calcium, Potassium, Sodium and Zinc) were measured in ash solution using Perkin Elmer atomic absorption spectrometer (Model 2380) as according to the AOAC [24].

\subsubsection{Amino Acid Composition}

Amino acid content was estimated as described by Moore et al., [26]. Amino acids were determined using an AAA 400 automatic amino acid analyzer (INGOS, Czech Republic). Prior to analysis; samples were subjected to acid hydrolysis in the presence of $6 \mathrm{ml} \mathrm{HCl}$ at $105^{\circ} \mathrm{C}$ for 24 hours. Sulphurcontaining amino acids were measured separately in $6 \mathrm{ml}$ $\mathrm{HCl}$ after oxidative hydrolysis (formic acid + hydrogen peroxide, 9:1 v/v, $20 \mathrm{~h}$ at $4^{\circ} \mathrm{C}$ ). Chemical Score was 
calculated according to FAO/WHO /UNU [27].

$$
\mathrm{C} . \mathrm{S}=\frac{\mathrm{mg} \text { of essential amino acid in g protein sample }}{\text { mg essential amino acid in requirement pattern }}
$$

\subsubsection{Physicochemical Analysis}

\section{(i). Bulk Density}

Bulk density was determined by the method of Murphy et al., [28] the sample was filled up a $10 \mathrm{ml}$ graduated cylinder up to the $10 \mathrm{ml}$ mark. The cylinder was tapped (agitated) for $5 \mathrm{~min}$. The weight of the filled cylinder was taken and the bulk density was calculated as the weight of sample per unit volume $(\mathrm{g} / \mathrm{ml})$.

\section{(ii). Water and Oil Absorption Capacity}

Water absorption capacity were determined according to the methods described by Wani and Kumar [29] It weighs $1 \mathrm{~g}$ of the sample and then put 10 distilled water and it was stirred for $30 \mathrm{~min}$ using a glass bar and then put the centrifuge at $2200 \times \mathrm{g}$ for $30 \mathrm{~min}$ The water was emitted from the centrifuge is disposed.

\section{(iii). Swelling Capacity}

Swelling capacity was Estimated by the method of Raghavendra et al., [30] it weighed dry sample $0.2 \mathrm{~g}$ then put graduated cylinder and added to $10 \mathrm{ml}$ distilled water and leave at $18 \mathrm{~h}$. After $18 \mathrm{~h}$, the final the increase in sample volume is calculated Swelling capacity $(\mathrm{ml} / \mathrm{g})=$ Volume occupied by sample/ Original sample weight.

\section{(iv). $\mathrm{pH}$ Value}

The $\mathrm{pH}$ value was estimated by mixing $10 \mathrm{~g}$ of sample with $100 \mathrm{ml}$ distilled water AOAC, [24].

\subsubsection{Bioactive Compounds}

(i). Determination of Total Phenols and Antioxidant Activity

The total phenolic contents as\% Gallic acid of healthy chips were determined by folin- Ciocalteau regent $(1: 10$ diluted) was added to $0.2 \mathrm{ml}$ of methanolic extract after 4 min thus $0.8 \mathrm{ml}$ of $\mathrm{Na}_{2} \mathrm{CO}_{3}$ solution and after $30 \mathrm{~min}$ incubation at the room temperature, thus, the samples were centrifuged at $5.000 \mathrm{rpm}$ for $10 \mathrm{~min}$. the absorbance was measured at $765 \mathrm{~nm}$ Li et al., [31].

Radical scavenging activity of chips sample was measured using the DPPH (2, 2-diphenyl-1-picrylhydrazyl) according to Brandwilliams et al., [32]. The percentage of DPPH scavenging for chips sample was calculated as follows:

$$
\text { Scavenging DPPH\% }=\left[\mathrm{Abs}_{\text {control }}-\mathrm{Abs}_{\text {sample }}\right) \times 100 / \mathrm{Asb}_{\text {control }}
$$

\subsubsection{Sensory Evaluation of Healthy Chips}

Color, taste, odor, texture, and overall acceptability of health chips were assessed using 10 panelists of home economics department, Faculty of Agriculture, Alexandria University, the panelists were asked to score the above attributes according to standard hedonic rating scale from 9 (like extremely) to 1 (dislike extremely) according Kramer and. Twigg [33].

\subsubsection{Statistical Analysis}

All data of the present study were expressed as mean values \pm SD Statistical analysis system (SAS) software program SAS Institute [34] was carried out by (ANOVA) followed by using t Tests (LSD) at $\mathrm{P} \leq 0.05$ which indicated statistically significant difference.

\section{Results and Discussion}

\subsection{Proximate Chemical Composition of Raw Material}

proximate chemical composition of raw material are shown in Table 2 The results of proximate chemical composition indicated that lupine flour contained significant higher amounts of crude protein, Crude ether extract and crude fiber $(43.17,9.90$ and $11.56 \%$, respectively) compared with these of potato and green pea flour $(6.14,0.83,4.41 \%$ and $24.18,2.11,4.39 \%$, respectively) on the other hand potato flour contained significant higher amounts of moisture, Ash, carbohydrates and energy values (10.40, 4.19, $74.02 \%$ and $309.69 \mathrm{Kcal} / 100 \mathrm{~g}$, respectively) compared with lupine and green pea flour $(10.11,3.52,21.73$, $219.19 \mathrm{Kcal} / 100 \mathrm{~g}$, respectively). These results are nearly in accordance with those reported by Ahmed [35], Wani and Kumar [29] and Kaur and Aggarwal [36].

Table 2. Proximate chemical composition of raw material.

\begin{tabular}{llll}
\hline \multirow{2}{*}{ Components } & Flour & & \\
\cline { 2 - 4 } & Potato & Lupine & Green pea \\
\hline Moisture & $10.40 \pm 0.14^{\mathrm{a}}$ & $10.11 \pm 0.15^{\mathrm{ab}}$ & $9.96 \pm 0.06^{\mathrm{b}}$ \\
Crude protein $(\mathrm{N} \times 6.25)$ & $6.14 \pm 0.26^{\mathrm{c}}$ & $43.17 \pm 0.14^{\mathrm{a}}$ & $24.11 \pm 0.15^{\mathrm{b}}$ \\
Crude ether extract & $0.83 \pm 0.06^{\mathrm{c}}$ & $9.90 \pm 0.14^{\mathrm{a}}$ & $2.11 \pm 0.15^{\mathrm{b}}$ \\
Ash & $4.19 \pm 0.97^{\mathrm{a}}$ & $3.52 \pm 0.74^{\mathrm{a}}$ & 0.62 \\
carbohydrate & $74.02 \pm 1.03^{\mathrm{a}}$ & $21.73 \pm 0.35^{\mathrm{c}}$ & 0.4 \\
Crude fiber & $4.41 \pm 0.12^{\mathrm{b}}$ & $11.56 \pm 0.54^{\mathrm{a}}$ & $2.85 \pm 0.21^{\mathrm{a}}$ \\
Energy Value (Kcal/100g) & $309.69 \pm 3.88^{\mathrm{a}}$ & $219.19 \pm 0.28^{\mathrm{c}}$ & $4.39 \pm 0.50^{\mathrm{b}}$ \\
\hline
\end{tabular}

Values followed by the same letter in a row are not significantly different at $\mathrm{p}<0.05$

\subsection{Proximate Chemical Composition of Healthy Chips}

Table 3 shows the proximate chemical composition of healthy chips, the moisture content ranged between $7.43 \%$ to
$8.77 \%$. In general, chips products with varies ingredients were low in moisture content, this value is nearly to some extent with those previously reported for dried potato chip $12.30 \%$ [37], however the moisture content affects its crispy 
stability and acceptance quality.

The protein content ranged from $7.89 \%$ to $16.07 \%$ and the significantly highest content was for the sample A while the significantly lowest content was for the sample G. Protein is one of the essential elements necessary for the growth and division of cells, including essential amino acids and essential for building the body, the range of protein content was within $8.17 \%$ to $12.29 \%$ which agreed with what reported by Adedapo et al., [10].

The Crude ether extract content ranged from 3.90\% to $6.31 \%$ and the significantly lowest content was for the control while the significantly highest content was for the sample F and G. Coorey et al., [38] found that crude fat content ranged from $3.88 \%$ to $3.32 \%$ also no significant difference in fat content between each five chips samples. These results are in agreement with those found by Cruz et al., [39] they are observed a positive relationship between moisture content and fat in potato chips.

The Ash content ranged from $3.00 \%$ to $3.75 \%$. The results revealed that no significant difference in Ash content for the all samples. In accordance it was reported that the Ash content of Pringles ranged between $3.49 \%$ and $4.73 \%$ Adedapo et al., [10] which shows a slight difference from this result. Also these results are in accordance with those reported by Kaur and Aggarwal [36] they found that the ash content of the chips ranged from $3.10 \%$ to $3.34 \%$ and no significant difference for the all chips samples.

The Crude fiber content ranged from $2.75 \%$ to $4.12 \%$ and the results showed the significantly $(\mathrm{P}<0.05)$ highest fiber content was found in the sample $G$ compared to the control sample. Osiriphun et al., [37] found that the crude fiber content of dried potato chip and Fried potato chip were $1.74 \%$ and $1.39 \%$ respectively. Gomez et al., [40] found that dietary fibers play an important role in human health as it has a protective role against cardiovascular diseases, diverticulosis, constipation, irritable colon, colon cancer and diabetes.

The carbohydrate content ranged from $61.66 \%$ in the sample $\mathrm{G}$ to $74.77 \%$ in the sample A. these value is nearly to the value of 53.36 to 61.12 which reported by Adedapo et al., [10]. The energy values were the lowest for sample $G$ and the highest for sample D.

Table 3. Proximate chemical composition of healthy chips.

\begin{tabular}{|c|c|c|c|c|c|c|c|c|}
\hline \multirow{2}{*}{ Components } & \multicolumn{7}{|c|}{ Chips products } & \multirow{2}{*}{ L.S.D } \\
\hline & $\mathbf{A}$ & B & $\mathbf{C}$ & D & $\mathbf{E}$ & $\mathbf{F}$ & G & \\
\hline Moisture & $7.43 \pm 0.09^{\mathrm{ab}}$ & $7.93 \pm 0.16^{\mathrm{ab}}$ & $7.70 \pm 0.65^{\mathrm{ab}}$ & $6.84 \pm 0.95^{\mathrm{b}}$ & $7.61 \pm 0.15^{\mathrm{ab}}$ & $7.30 \pm 0.88^{\mathrm{ab}}$ & $8.77 \pm 0.14^{\mathrm{a}}$ & 1.32 \\
\hline Crude protein $(\mathrm{N} \times 6.25)$ & $7.89 \pm 0.15^{\mathrm{e}}$ & $11.80 \pm 0.56^{\mathrm{c}}$ & $13.86 \pm 0.90^{\mathrm{b}}$ & $9.45 \pm 0.07^{\mathrm{d}}$ & $10.11 \pm 0.04^{\mathrm{d}}$ & $13.30 \pm 0.51^{\mathrm{b}}$ & $16.07 \pm 0.11^{\mathrm{a}}$ & 1.07 \\
\hline Crude ether extract & $3.90 \pm 1.27^{\mathrm{b}}$ & $5.90 \pm 0.14^{\mathrm{a}}$ & $6.10 \pm 0.42^{\mathrm{a}}$ & $5.40 \pm 0.85^{\mathrm{a}}$ & $5.70 \pm 0.14^{\mathrm{a}}$ & $6.20 \pm 0.28^{\mathrm{a}}$ & $6.31 \pm 0.72^{\mathrm{a}}$ & 1.59 \\
\hline Ash & $3.25 \pm 0.35^{\mathrm{a}}$ & $3.50 \pm 0.0^{\mathrm{a}}$ & $3.75 \pm 0.35^{\mathrm{a}}$ & $3.00 \pm 0.00^{\mathrm{a}}$ & $3.12 \pm 0.53^{\mathrm{a}}$ & $3.00 \pm 0.71^{\mathrm{a}}$ & $3.05 \pm 0.87^{\mathrm{a}}$ & 1.14 \\
\hline carbohydrate & $74.77 \pm 1.22^{\mathrm{a}}$ & $67.23 \pm 1.04^{\mathrm{c}}$ & $64.71 \pm 1.45^{\mathrm{d}}$ & $72.06 \pm 0.68^{b}$ & $70.07 \pm 0.30^{b}$ & $66.71 \pm 0.23^{\mathrm{cd}}$ & $61.66 \pm 1.46^{\mathrm{e}}$ & 2.43 \\
\hline Crude fiber & $2.75 \pm 0.35^{\mathrm{c}}$ & $3.62 \pm 0.18^{\mathrm{ab}}$ & $3.87 \pm 0.18^{\mathrm{ab}}$ & $3.25 \pm 0.71^{\mathrm{bc}}$ & $3.37 \pm 0.18^{\mathrm{ab}}$ & $3.87 \pm 0.28^{\mathrm{ab}}$ & $4.12 \pm 0.18^{\mathrm{a}}$ & 0.79 \\
\hline
\end{tabular}

Values followed by the same letter in a row are not significantly different at $\mathrm{p}<0.05$

\subsection{Mineral Content of Raw Material}

The results of minerals content of raw Material are shown in table 4 The lupine flour contained higher element of Iron and Zinc (13.35and $7.80 \mathrm{mg} / 100 \mathrm{~g}$, respectively) compared with those values of potato and green pea flour (4.30, $5.52 \mathrm{mg} / 100 \mathrm{~g})$ and $(8.20$ and $7.45 \mathrm{mg} / 100 \mathrm{~g}$ respectively $)$. While The green pea flour contained higher amounts of calcium and potassium (438.50 and $1032.50 \mathrm{mg} / 100 \mathrm{~g}$, respectively) compared with these values of potato and lupine flour (101.25, $837 \mathrm{mg} / 100 \mathrm{~g})$ and (199.75, $925 \mathrm{mg} / 100 \mathrm{~g})$, respectively. Finally, potato flour contains a high amount of sodium $90 \mathrm{mg} / 100 \mathrm{~g}$ compared with green pea and lupine flour $(54,19.15 \mathrm{mg} / 100 \mathrm{~g}$, respectively. Adrogue et al., [41] found that reported that potassium is very importent to Transport of electrical charges in the nervous system and It also contributes to the reduction of high blood pressure.

Kaur and Kochhar [42] reported that the potato flour contents of iron $3.82 \mathrm{mg} / 100 \mathrm{~g}$, while the value of calcium contents about $9.38 \mathrm{mg} / 100 \mathrm{~g}$.

Pallavi et al., [43] found that the pea contains some mineral such as iron, calcium and zinc, in addition currently used as a vegetable in the preparation of snacks [44]. Muhammad et al., [45] reported that raw lupine seeds contents $735.04 \mathrm{mg} / 100 \mathrm{~g}$ potassium, $173.05 \mathrm{mg} / 100 \mathrm{~g}$ calcium, $3.59 \mathrm{mg} / 100 \mathrm{~g}$ iron, 3.50 $\mathrm{mg} / 100 \mathrm{~g}$ zinc and 34.03 Sodium.

Table 4. Minerals Content of potato, lupine and green pea flour ( $\mathrm{mg} / 100 \mathrm{~g}$ ) on dry weight basis.

\begin{tabular}{llll}
\hline Element & Potato flour & Lupine flour & Green pea flour \\
\hline Iron & 4.30 & 13.35 & 8.20 \\
Calcium & 101.25 & 199.75 & 438.50 \\
Potassium & 837.00 & 925.35 & 1032.50 \\
Sodium & 90.00 & 19.15 & 54.00 \\
Zinc & 2.52 & 7.80 & 7.45 \\
\hline
\end{tabular}

\subsection{Mineral Content of Healthy Chips}

Mineral contents of healthy chips are given in table 5. The results indicated that iron and calcium content of Chips products ranged from 3.52 to $4.84 \mathrm{mg} / 100 \mathrm{~g}$ and 104.0 to $296.9 \mathrm{mg} / 100 \mathrm{~g}$ respectively. The iron contents values were the lowest for the sample A and the highest for sample G. On the other hand, the value of calcium contents was the highest for the sample G, Potassium and sodium contents ranged from 720 to $812 \mathrm{mg} / 100 \mathrm{~g}$ and 1012.35 to $1195.5 \mathrm{mg} / 100 \mathrm{~g}$ respectively. The sample $\mathrm{G}$ was the highest in the potassium content and the lowest value was in the sample $\mathrm{A}$, moreover the sodium value was lowest content in sample $\mathrm{G}$.

Zinc content ranged from 2.22 to $6.98 \mathrm{mg} / 100 \mathrm{~g}$, the sample $\mathrm{G}$ was the highest in the zinc content while the lowest 
was found in the sample A.

Table 5. Minerals Content of healthy chips ( $\mathrm{mg} / 100 \mathrm{~g})$ on dry weight basis.

\begin{tabular}{|c|c|c|c|c|c|c|c|}
\hline \multirow{2}{*}{ Element } & \multicolumn{7}{|c|}{ Chips Products } \\
\hline & $\mathbf{A}$ & B & $\mathrm{C}$ & D & $\mathbf{E}$ & $\mathbf{F}$ & G \\
\hline Iron & 3.52 & 3.98 & 4.12 & 3.74 & 3.98 & 4.40 & 4.84 \\
\hline Calcium & 104.00 & 176.00 & 199.80 & 263.10 & 280.90 & 272.30 & 296.90 \\
\hline Potassium & 720.00 & 742.00 & 755.00 & 746.00 & 790.00 & 768.00 & 812.00 \\
\hline Sodium & 398.5 & 375.6 & 339.2 & 394.4 & 359.2 & 341.7 & 337.45 \\
\hline Zinc & 2.22 & 6.60 & 6.84 & 5.00 & 5.70 & 6.80 & 6.98 \\
\hline
\end{tabular}

\subsection{Amino Acids Composition}

The amino acids composition of raw material belonging to each of: potato, lupine and green pea flour are shown in table 6 . It was obvious that lupine flour is higher than potato, green pea flour and whey powder in lysine, leucine, isoleucine, tyrosine and valine. On the other hand, lupine flour is higher in glutamic $(7.46 \mathrm{~g} / 100 \mathrm{~g})$ and Arginine $(3.80 \mathrm{~g} / 100 \mathrm{~g})$ than the potato and green pea flour $(0.88 \mathrm{~g} / 100 \mathrm{~g}$ protein, 0.45 $\mathrm{g} / 100 \mathrm{~g})$ and $(3.29 \mathrm{~g} / 100 \mathrm{~g}, 1.79 \mathrm{~g} / 100 \mathrm{~g})$ respectively. These results are agreement with those reported by Ahmed [35] who found that the essential amino acid (lysine, threonine, isoleucine, phenylalanine and arginine high content in lupine flour were recorder $1.63 \mathrm{~g} / 100 \mathrm{~g}, 1.14 \mathrm{~g} / 100 \mathrm{~g}, 1.48 \mathrm{~g} / 100 \mathrm{~g}$, $1.42 \mathrm{~g} / 100 \mathrm{~g}, 3.61 \mathrm{~g} / 100 \mathrm{~g}$ respectively.

Lupine seeds represent a good balance of essential amino acids [46]. They are considered to be a good source of lysine, and are generally poor in the sulfur-containing amino acids methionine and cysteín. [47].

Table 6. Amino acids composition of raw Material.

\begin{tabular}{|c|c|c|c|c|}
\hline Amino acid (\%) protein & Potato flour & Lupine flour & Green pea flour & whey powder \\
\hline \multicolumn{5}{|l|}{ Essential a.a. } \\
\hline Histidine & 0.12 & 0.85 & 0.55 & 0.01 \\
\hline Isoleucine & 0.26 & 1.44 & 0.87 & 0.01 \\
\hline Lysine & 0.43 & 1.77 & 1.51 & 0.03 \\
\hline Methionine & 0.13 & 0.40 & 0.23 & --- \\
\hline Phenylalanine & 0.32 & 1.47 & 1.07 & --- \\
\hline Valine & 0.37 & 1.99 & 1.07 & 0.01 \\
\hline Total essential a.a & 2.34 & 11.69 & 7.56 & 0.08 \\
\hline \multicolumn{5}{|l|}{ Non-Essential a.a } \\
\hline Alanine & 0.29 & 1.30 & 1.00 & --- \\
\hline Arginine & 0.45 & 3.80 & 1.79 & --- \\
\hline Aspartic & 0.95 & 3.72 & 2.36 & 0.04 \\
\hline Cysteine & 0.15 & 0.69 & 0.38 & --- \\
\hline Glutamic & 0.88 & 7.46 & 3.29 & 0.17 \\
\hline Proline & 0.31 & 1.31 & 0.82 & --- \\
\hline Tyrosine & 0.27 & 1.85 & 0.81 & --- \\
\hline Serine & 0.25 & 1.67 & 0.88 & 0.01 \\
\hline Total Non-essential a.a & 3.81 & 23.21 & 12.23 & 0.25 \\
\hline
\end{tabular}

\subsection{Amino Acids Composition of Healthy Chips}

Table 7 shows amino acids composition of healthy chips. It was found that the sample G (70\% potato flour and $15 \%$ lupine flour and $15 \%$ green pea flour) contained high percentage of the essential amino acids which including (lysine, phenylalanine threonine and valine, $0.79,0.60,0.49$ and $0.72 \mathrm{~g} / 100 \mathrm{~g}$ ), respectively. While the sample $\mathrm{C}$ and $\mathrm{F}$ contented high in leucine compared with other samples. Also found that sample $\mathrm{G}$ had higher content of Arginine, Glutamic and Aspartic.

Table 7. Amino acids composition of healthy chips.

\begin{tabular}{|c|c|c|c|c|c|c|c|c|c|c|c|c|c|c|c|}
\hline $\begin{array}{l}\text { Amino acid (\%) } \\
\text { protein }\end{array}$ & $\mathbf{A}$ & *CS & B & $* \mathrm{CS}$ & $\mathbf{C}$ & $* \mathrm{CS}$ & D & ${ }^{*} \mathrm{CS}$ & $\mathbf{E}$ & ${ }^{*} \mathrm{CS}$ & $\mathbf{F}$ & ${ }^{*} \mathrm{CS}$ & G & ${ }^{*} \mathrm{CS}$ & $\begin{array}{l}\text { FAO/WHO } \\
\text { Pattern } \\
(\mathbf{2 0 0 2})\end{array}$ \\
\hline \multicolumn{16}{|l|}{ Essential A. A. } \\
\hline Histidine & 0.12 & 6.68 & 0.19 & 10.74 & 0.23 & 12.77 & 0.16 & 9.07 & 0.19 & 10.27 & 0.27 & 13.13 & 0.29 & 1.64 & 1.8 \\
\hline Isoleucine & 0.26 & 6.20 & 0.38 & 9.01 & 0.44 & 10.41 & 0.32 & 7.65 & 0.35 & 8.38 & 0.44 & 10.46 & 0.53 & 1.26 & 4.2 \\
\hline Leucine & 0.45 & 7.15 & 0.66 & 10.40 & 0.76 & 12.03 & 0.56 & 8.83 & 0.61 & 9.67 & 0.76 & 12.08 & 0.92 & 1.46 & 6.3 \\
\hline Lysine & 0.43 & 8.29 & 0.56 & 10.86 & 0.63 & 12.15 & 0.54 & 10.36 & 0.59 & 11.40 & 0.67 & 12.94 & 0.79 & 1.53 & 5.2 \\
\hline
\end{tabular}




\begin{tabular}{|c|c|c|c|c|c|c|c|c|c|c|c|c|c|c|c|}
\hline $\begin{array}{l}\text { Amino acid (\%) } \\
\text { protein }\end{array}$ & $\mathbf{A}$ & $* \mathrm{CS}$ & B & *CS & $\mathbf{C}$ & $* \mathrm{CS}$ & D & $* \mathrm{CS}$ & $\mathbf{E}$ & ${ }^{*} \mathrm{CS}$ & $\mathbf{F}$ & $* \mathrm{CS}$ & G & $* \mathrm{CS}$ & $\begin{array}{l}\text { FAO/WHO } \\
\text { Pattern } \\
(2002)\end{array}$ \\
\hline Phenylalanine & 0.32 & 11.43 & 0.44 & 15.54 & 0.49 & 17.59 & 0.40 & 14.11 & 0.43 & 15.45 & 0.51 & 18.21 & 0.60 & 2.16 & 2.8 \\
\hline Threonine & 0.26 & 9.64 & 0.36 & 13.38 & 0.41 & 15.25 & 0.31 & 11.46 & 0.33 & 12.36 & 0.41 & 15.20 & 0.49 & 1.80 & 2.7 \\
\hline Valine & 0.37 & 8.82 & 0.53 & 12.67 & 0.61 & 14.60 & 0.44 & 10.48 & 0.48 & 11.32 & 0.60 & 14.34 & 0.72 & 1.71 & 4.2 \\
\hline Total essential a.a & 2.34 & & 3.28 & & 3.74 & & 2.86 & & 3.13 & & 3.80 & & 4.53 & & \\
\hline Non-Essential A. A. & & & & & & & & & & & & & & & \\
\hline Arginine & 0.45 & & 0.79 & & 0.95 & & 0.58 & & 0.65 & & 0.919 & & 1.15 & & \\
\hline Aspartic & 0.95 & & 1.23 & & 1.37 & & 1.09 & & 1.16 & & 1.37 & & 1.58 & & \\
\hline Cysteine & 0.15 & & 0.20 & & 0.23 & & 0.17 & & 0.19 & & 0.23 & & 0.27 & & \\
\hline Glutamic & 0.89 & & 1.54 & & 1.87 & & 1.13 & & 1.25 & & 1.75 & & 2.23 & & \\
\hline Glycine & 0.26 & & 0.38 & & 0.43 & & 0.33 & & 0.36 & & 0.44 & & 0.53 & & \\
\hline Proline & 0.31 & & 0.41 & & 0.46 & & 0.36 & & 0.39 & & 0.46 & & 0.54 & & \\
\hline Tyrosine & 0.27 & & 0.43 & & 0.51 & & 0.32 & & 0.35 & & 0.48 & & 0.59 & & \\
\hline $\begin{array}{l}\text { Total Non-essential } \\
\text { a.a }\end{array}$ & 3.82 & & 5.63 & & 6.53 & & 4.66 & & 5.08 & & 6.47 & & 7.80 & & \\
\hline
\end{tabular}

*CS: The chemical score

\subsection{Physicochemical Analysis of Healthy Chips}

The data presented in table 8 revealed that bulk density ranged from 0.74 to $0.91 \mathrm{~g} / \mathrm{ml}$, the results also showed the significantly $(\mathrm{P}<0.05)$ highest bulk density was found in the sample E compared to the control sample. This may be due the high fiber content in the sample E (85\% potato flour and $15 \%$ green pea flour). These results are in accordance with those reported by Shadan et al., [48] The bulk density of products determined the volume of occupy in package materials, it also depends on the characteristics of the composition of the product, the particle size and the extent of its spread, and also other physiochemical properties [49].

Water absorption capacity plays an important role in the process of preparing food products, and has been found to affect the sensory and functional properties of the product. The absorption of water in the pulses flour helps maintain the soft texture of the resulting product because the pulses contain polysaccharides, in general absorption of water is affected by protein quality $[50,29]$. The WAC value ranged from 1.70 to $1.94 \mathrm{~g} / \mathrm{g}$. The significantly $(\mathrm{P}<0.05)$ highest WAC was found in the sample A (100\% potato flour) and the lowest for the sample B $(90 \%$ potato flour and $10 \%$ lupine flour). Chandra et al., [51] found that Potato flour was the highest value of water absorption capacity due to the high content of carbohydrates and fiber in a large amount of potato flour. The absorption of water has an important function of protein in the food products such as soup, dough and baked. Wani and Kumar [29] also observed that high water absorption capacity in dried green pea flour due to the high content of hydrophilic materials such as soluble fiber and low fat content.

The Swelling capacity value ranged from $1.12 \mathrm{ml} / \mathrm{g}$ in the sample A to $1.95 \mathrm{ml} / \mathrm{g}$ in the sample G. Swelling capacity refers to how much water with sample in order to know the amount of flour needed to form a dough and depends on the composition of the sample and the different cooking methods of food and the size of particle, and its proportion varies in snacks based on potato flour snacks $[51,10]$. The results obtain in the present study are in agreement with those reported by Kohajdová et al., [52] they observed that swelling capacity is high in pea flour, so it could be used in food that needs swelling such as extrusion.

$\mathrm{pH}$ is important in estimating alkalinity and acidity of food where it determines microbial growth and damage to the product. A few of organisms able to grow at low $\mathrm{pH}$. The $\mathrm{pH}$ value ranged from 5.44 to 5.89 , also There were significant differences between every chips samples. These value are comparable to the value of 5.48 to 6.16 reported by Adedapo et al., [10].

Table 8. Physicochemical analysis of healthy chips.

\begin{tabular}{|c|c|c|c|c|c|c|c|c|}
\hline \multirow{2}{*}{ Properties } & \multicolumn{7}{|c|}{ Chips Products } & \multirow{2}{*}{ L.S.D } \\
\hline & $\mathbf{A}$ & B & C & D & $\mathbf{E}$ & $\mathbf{F}$ & $\mathbf{G}$ & \\
\hline Bulk Density & $0.74 \pm 0.01^{\mathrm{c}}$ & $0.77 \pm 0.04^{\mathrm{bc}}$ & $0.74 \pm 1.35^{\mathrm{c}}$ & $0.89 \pm 0.00^{\mathrm{a}}$ & $0.91 \pm 0.01^{\mathrm{a}}$ & $0.71 \pm 0.01^{\mathrm{b}}$ & $0.79 \pm 0.00^{\mathrm{b}}$ & 0.04 \\
\hline WAC & $1.94 \pm 0.03^{\mathrm{a}}$ & $1.70 \pm 0.03^{\mathrm{b}}$ & $1.73 \pm 0.06^{\mathrm{b}}$ & $1.81 \pm 0.14^{\mathrm{ab}}$ & $1.85 \pm 0.06^{\mathrm{ab}}$ & $1.71 \pm 0.03^{\mathrm{b}}$ & $1.73 \pm 0.01^{\mathrm{b}}$ & 0.15 \\
\hline Swelling Capacity & $1.12 \pm 0.03^{\mathrm{c}}$ & $1.45 \pm 0.08^{\mathrm{bc}}$ & $1.65 \pm 0.08^{\mathrm{ab}}$ & $1.43 \pm 0.37^{\mathrm{bc}}$ & $1.75 \pm 0.07^{\mathrm{ab}}$ & $1.85 \pm 0.07^{\mathrm{a}}$ & $1.95 \pm 0.07^{\mathrm{a}}$ & 0.36 \\
\hline $\mathrm{pH}$ & $5.57 \pm 0.02^{\mathrm{d}}$ & $5.50 \pm 0.02^{\mathrm{e}}$ & $5.44 \pm 0.02^{\mathrm{f}}$ & $5.76 \pm 0.02^{\mathrm{b}}$ & $5.89 \pm 0.02^{\mathrm{a}}$ & $5.72 \pm 0.02^{\mathrm{bc}}$ & $5.68 \pm 0.02^{\mathrm{cd}}$ & 0.05 \\
\hline
\end{tabular}

Values followed by the same letter in a row are not significantly different at $\mathrm{p}<0.05$

\subsection{Bioactive Compounds of Healthy Chips}

3.8.1. Total Phenolic Content and Antioxidant Activity Total phenol and antioxidants activity are shown in table 9.
The results revealed that sample G $(70 \%$ potato flour and $15 \%$ lupine flour and $15 \%$ green pea flour) significantly have the highest amounts of total phenolic content (1783.64 $\mathrm{mg} / 100 \mathrm{~g}$ ), while the lowest contents value was 790.84 
$\mathrm{mg} / 100 \mathrm{~g}$ found in sample A. The high total phenolic content in chips from potato, lupine and green pea flour refer to their higher content of phytonutrients including phenolic and flavonoids which important for health and functional foods [35]. These values are higher than those reported by [36] they mentioned that total phenol content ranged between 100.10 to $200.01 \mathrm{mg} / 100 \mathrm{~g}$ in maize potato tortilla chips. As well Ettoumi and Chibane [53] reported that total phenolic content in green pea was $236 \mathrm{mg} / 100 \mathrm{~g}$.
Antioxidant activity of the product chips ranged from $82.78 \%$ to $97.16 \%$, where the significantly highest activity was recorded in sample $\mathrm{G}$ while the significantly lowest was found in the sample A. these results confirmed the possibility of using green pea and lupine flour as a good antioxidant source. These results are more in accordance with those reported by Ettoumi and Chibane [53], Kaur and Aggarwal [36].

Table 9. Bioactive compound of healthy chips.

\begin{tabular}{|c|c|c|c|c|c|c|c|}
\hline \multirow{2}{*}{ Component } & \multicolumn{7}{|l|}{ Chips products } \\
\hline & $\mathbf{A}$ & B & $\mathbf{C}$ & D & $\mathbf{E}$ & $\mathbf{F}$ & $\mathbf{G}$ \\
\hline $\begin{array}{l}\text { Total Phenolic } \\
\text { content }(\mathrm{mg} / 100 \mathrm{~g})\end{array}$ & $790.84 \pm 87.98^{e}$ & $849.79 \pm 3.20^{\text {ed }}$ & $890.38 \pm 36.33^{\mathrm{d}}$ & $1014.54 \pm 37.16^{\mathrm{c}}$ & $1034.22 \pm 20.12^{\mathrm{c}}$ & $1454.75 \pm 30.62^{\mathrm{b}}$ & $1783.64 \pm 9.87^{\mathrm{a}}$ \\
\hline $\begin{array}{l}\text { Antioxidant } \\
\text { activity (\%) }\end{array}$ & $82.78 \pm 2.19^{d}$ & $87.18 \pm 2.66^{\mathrm{c}}$ & $88.57 \pm 2.19^{b}$ & $91.64 \pm 0.96^{\mathrm{cb}}$ & $96.27 \pm 3.13^{\mathrm{a}}$ & $96.76 \pm 2.33^{\mathrm{a}}$ & $97.16 \pm 1.82^{\mathrm{a}}$ \\
\hline
\end{tabular}

Values followed by the same letter in a row are not significantly different at $\mathrm{p}<0.05$

\subsection{Sensory Evaluation}

Sensory attributes including color, taste, odor, texture, overall acceptability of the studies healthy chips for malnourished children are present in table 10 . It could be observed that all the sample there no significant difference at $(\mathrm{P}<0.05)$ between all the sensory properties whether prepared from potato flour only or potatoes flour and lupine or potatoes flour and green pea, or potato flour, lupine and green pea. Generally, it can be noted that flour of potatoes, lupine and green pea can be used in the preparation of chips successfully and increased the overall acceptability of the healthy chips. These results agreed well with those reported by Kaur and Aggarwal [36].

Table 10. Sensory evaluation of healthy chips.

\begin{tabular}{|c|c|c|c|c|c|c|c|c|}
\hline \multirow{2}{*}{ Properties } & \multicolumn{7}{|c|}{ Chips products } & \multirow{2}{*}{ L.S.D } \\
\hline & $\mathbf{A}$ & B & $\mathbf{C}$ & D & $\mathbf{E}$ & $\mathbf{F}$ & $\mathbf{G}$ & \\
\hline Color & $8.70 \pm 0.94^{\mathrm{ab}}$ & $8.30 \pm 0.93^{\mathrm{ab}}$ & $8.30 \pm 1.16^{\mathrm{ab}}$ & $8.50 \pm 0.70^{\mathrm{ab}}$ & $8.90 \pm 0.74^{\mathrm{a}}$ & $7.70 \pm 1.16^{\mathrm{b}}$ & $7.60 \pm 1.35^{\mathrm{b}}$ & 0.92 \\
\hline Taste & $8.00 \pm 1.45^{\mathrm{ab}}$ & $7.70 \pm 1.04^{\mathrm{ab}}$ & $8.30 \pm 0.95^{\mathrm{ab}}$ & $8.50 \pm 1.08^{\mathrm{ab}}$ & $8.80 \pm 0.63^{\mathrm{ab}}$ & $7.40 \pm 1.43^{\mathrm{a}}$ & $7.40 \pm 1.58^{\mathrm{b}}$ & 1.16 \\
\hline Odor & $8.00 \pm 1.96^{\mathrm{a}}$ & $8.30 \pm 1.25^{\mathrm{a}}$ & $8.20 \pm 1.47^{\mathrm{a}}$ & $8.20 \pm 1.33^{\mathrm{a}}$ & $8.40 \pm 0.97^{\mathrm{a}}$ & $8.20 \pm 1.03^{\mathrm{a}}$ & $7.50 \pm 2.12^{\mathrm{a}}$ & 1.29 \\
\hline Texture & $8.10 \pm 1.45^{\mathrm{a}}$ & $7.80 \pm 1.37^{\mathrm{a}}$ & $8.10 \pm 0.95^{\mathrm{a}}$ & $8.20 \pm 1.22^{\mathrm{a}}$ & $8.30 \pm 1.25^{\mathrm{a}}$ & $7.40 \pm 1.43^{\mathrm{a}}$ & $7.10 \pm 2.13^{\mathrm{a}}$ & 1.28 \\
\hline Overall acceptability & $8.40 \pm 1.07^{\mathrm{a}}$ & $8.40 \pm 1.25^{\mathrm{a}}$ & $8.40 \pm 0.84^{\mathrm{a}}$ & $8.50 \pm 0.97^{\mathrm{a}}$ & $8.70 \pm 0.95^{\mathrm{a}}$ & $7.70 \pm 1.34^{\mathrm{a}}$ & $7.70 \pm 1.77^{\mathrm{a}}$ & 1.08 \\
\hline
\end{tabular}

Values followed by the same letter in a row are not significantly different at $\mathrm{p}<0.05$

\section{Conclusion}

The data in this study show the potential of exploiting each of potato, lupine and pea flour in snack food items such as chips and all the samples were well accepted by the panelists. And these chips are used to improve the nutritional status of malnourished children especially protein and energy. In addition, minerals such as (calcium, potassium, sodium, iron and zinc). Finally, potato, lupine and pea chips could be considered as one of the best types of healthy chips ready to eat for children and adults alike.

\section{References}

[1] Greco, L., Balungi, J., Amono, K., Iriso, R. and Corrado B. 2006. Effect of a low cost food on the recovery and death rate of malnourished children. J Pediatr Gastroenterol Nutr. 43: 512-517.

[2] WHO 2013. "Severe acute malnutrition", available at: www. who. int/nutrition/topics/en/index. html (accessed 4 September 2013).

[3] Salvador, A., Varela, P., Sanz, T. and Fiszman, S. M. 2009. Understanding Potato Chips Crispy Texture by Simultaneous Fracture and Acoustic Measurements, and Sensory Analysis. LWT - Food Science and Technology, vol. 42, no 3, https://doi.org/10.1016/j.lwt.2008.09. 016.

[4] Zhang, Y., Zhang, G. and Zhang Y. 2005. Occurrence and Analytical Methods of Acrylamide in Heat-treated Foods: Review and Recent Developments, "Journal of Chromatography", no 1075, https://doi.org/10.1016/j.chroma.2005.03.123.

[5] Suna, S., Tamar, C. E., Incedayi B, Sinir, G. O. and Copur, O. U. 2014. Impact of drying methods on physiochemical and sensory proerpites of apricot pestil. Indian Journal of Traditional Knowledge, 13: 47-55.

[6] Yi, H., Hwang L. T., Choi H. and Lim, H. 2015. Physicochemical and Organoleptic Characteristics of Deep-fat Fried and Microwaved Potato Chips, "Journal of the Korean Society for Applied Biological Chemistry", vol. 58, no 5, https://doi.org/10.1007/s137650150101-3. 
[7] Moros J., Roth M., Garrigues S., de la Guardia, M. 2009. Preliminary Studies about Thermal Degradation of Edible Oils through Attenuated Total Reflectance Mid Infrared Spectrometry, "Food Chemistry", vol. 114, no 4, https://doi.org/10.1016/j.foodchem.11.040.

[8] Kittipadakul, P., Jaipeng, B., Slter, A., Stevenson, W., and Jansky, S. 2016. Potato production in Thailand. American Journal of Potato Research, 93: 380-385.

[9] Hassan, A. S. and Al-Dosari, S. N. 2008. Breakfast Habits and Snacks Consumed at School among Qatari Schoolchildren Aged 9-10 Years, Nutrition \& Food Science, vol. 38, no 3.

[10] Adedapo A. E., Oladapo A. O. and Adedoyin A. 2014. Production and Quality Evaluation of Pringles from Composite Flour of Cocoyam and Wheat Flour. Journal of Agricultural Science and Technology B 4: 285-290.

[11] FAO (2013), Food and Agricultural Commodities Production, Statistical Database, Food and Agriculture Organisation, available at: http://faostat.fao.org/site/339/default.aspx (accessed 10 September 2013).

[12] Gopalan, C. Rama, Sastri. B. V. and Balasubramanian, S. C. 2010. Nutritive Value of Indian Foods, National Institute of Nutrition, Hyderabad, pp. 48-98.

[13] Gumul, D., R. Ziobro, M. Noga, and R. Sabat. 2011. Characterization of five potato cultivars according to their nutritional and pro-health components. Acta Sci Pol Technol Aliment. 10 (1), 73-81.

[14] FAO (2007). Protein and amino acid requirements in human nutrition. Report of joint WHO/FAO/UNU Expert consultation, WHO Technical Report Series 935.

[15] Frias, j., giacomino, s. e., peñas, n., pellegrino, v., ferreyra, n., apro, m., olivera-c. c. and vidalvalverde 2011. Assessment of the nutritional quality of raw and extruded Pisum sativum L. var. laguna seeds. LWT - Food Sci. Technol., 44, 1303-1308.

[16] Sudha, M. L. and leelavathi, K. 2012. Effect of blends of dehydrated green pea $\mathrm{fl}$ our and amaranth seed flour on the rheological, microstructure and pasta making quality. J. Food Sci. Technol., 49, 713-720.

[17] Evans, A. J., Cheung P. C. K. and Cheetham, N. W. H. 1993. The carbohydrate composition of cotyledons and hulls of cultivars of Lupinus angustifolius from Western Australia. Journal of the Science of Food and Agriculture, 61: 189-194.

[18] Oomah, B. D., Tiger, N., Olson, M. and Balasubramanian, P. 2006. Phenolics and antioxidative activities in narrow-leafed lupins (Lupinus angustifolius L.). Plant Foods for Human Nutrition, 61: 91-97.

[19] Martínez-Villaluenga, C., Zielinski, H., Frias, J., Piskula, M. K., Kozlowska, H. and Vidal- Valverde, C. 2009. Antioxidant capacity and polyphenolic content of high-protein lupin products. Food Chemistry, 112: 84-88.

[20] Clark, R. and Johnson, S. 2002. Sensory acceptability of foods with added Lupin (Lupinus angustifolius) kernel fiber using pre-set criteria. J Food Sci, 67 (1): 356-362.

[21] Jayasena V., Abbas, N. S. M., Yii Y. J. and Senaratna, M 2009. Development of lupin based low cost, high fibre and high protein innovative foods. In: Proceedings of the
International Conference on Innovations in Food Processing Technology and Engineering (ICFPTE'08), 19-20 January, Thailand. pp. 1-10, Asian Institute of Technology, Pathumthani, Thailand.

[22] Jayasena, V., Khu W. S. and Abbas, N. S. M. 2010. The development and sensory acceptability of lupin-based tofu. Journal of Food Quality, 33, 85-97.

[23] Misra, A. and Kulshrestha, K. 2003. Effect of storage on nutritional value of potato flour made from three potato varieties. Plant Foods Hum. Nutr. 58: 1-10.

[24] AOAC. 2012. Official Methods of Analysis of the Association of Official Analytical Chemists, 19th ed, Arligton, Virginia, USA.

[25] Zambrano, F., Despinoy, P., Ormenese, R. C. S. C. and Faria, E. V. 2004. The use of guar and xanthan gums in the production of light low fat cakes. International Journal of food Science and Technology, 39: 959-966.

[26] Moore S, Spackman DH, Stein WH (1958) Chromatography of amino acids on sulphonated polistyrene resin. An improved system. Anal Chem 30: 1190-1196.

[27] FAO/WHO /UNU. 2002. Expert Consultation on protein and amino acid Requirements in human Nutrition, Geneva. Switzerland.

[28] Murphy, M. G., Skonberg, D. I. and Camire, M. E. (2003). Chemical composition and physical properties of extruded snacks containing crabprocessing products. J. Food Sci. Agric, 83: 1163-1167.

[29] Wani, S. A. and Kumar, P. 2014. Comparative study of chickpea and green pea flour based on chemical composition, functional and pasting properties. J Food Res Technol, 2 (3): 124- 129.

[30] Raghavendra S. N., Navin K Rastogi, K sms Raghavarao, R. N. Tharanathan 2004. Dietary fiber from coconut residue: Effects of different treatments and particle size on the hydration properties. European Food Research and Technology 218 (6): 563-567.

[31] Li, H. B., K. W. Cheng, C. C. Wong, K. W. Fan, F. Chen and Y. Jiang. 2007. Evaluation of antioxidant capacity and total phenolic content of different fractions of selected microalgae. Food Chem. 102: 771-776.

[32] Brandwilliams, W., Cuvelier, M. E. and Berset, C. 1995. Use of a free radical method to evaluate antioxidant activity. Food Sci Technol Lebensm Wiss Technol, 28 (1): 25-30.

[33] Kramer A. and. Twigg B. A. 1973. Quality Control for the Food Industry, Volume 2 - Applications. 3. Aufl. 550 Seiten, 58 Abb. 83 Tab. The AVI Publishing Company. Inc., Westport, Connecticut, USA,

[34] SAS. 2004, SAS Institute Inc. SAS. /ETS 9. 1 User SAS Institute Inc Users Guide. Cary, NC.

[35] Ahmed, A. R. A. 2012. Technological and Nutritional Studies on Sweet Lupine Seeds and its Applicability in Selected Bakery Products Institute of Food Technology and Food Chemistry, Technical University of Berlin.

[36] Kaur, S. and Aggarwal, P. 2017. Development of maize-potato tortilla chips: A nutritious and low fat snack food. Journal of Pharmacognosy and Phytochemistry, 6 (4): 153-161. 
[37] Osiriphun, S.; Wongsuriyasak, S. and Chakrabandhu, Y. 2018. Development of Potato Chips (Alou) with Northern Thai Green Chili Paste (Nam Phrik Noom) Flavor. Food and Applied Bioscience, 6 (2): 76-84.

[38] Coorey, R.; Grant, A. \& Jayasena, V. 2012. Effects of Chia Flour Incorporation on the Nutritive Quality and Consumer Acceptance of Chips Journal of Food Research. 1 (4): 8595.

[39] Cruz, G.; Tirado, J. P.; Delgado, K.; Guzman, Y.; Castro, F.; Rojas, M. L. and Linares, G. 2018. Impact of predrying and frying time on physical properties and sensorial acceptability of fried potato chips. J Food Sci Technol, 55 (1): $138-144$.

[40] Gomez, M., Ronda, F., Coballera, A. P.; Blanco, A. C. and Rosell, C. M. 2007. Functionality of different hydrocolloids on the quality and shelf life of yellow layer cakes. Food Hydrocolloids 21 (2), 167- 173.

[41] Adrogue, M. D., Madias, N. E. 2007. Sodium and potassium in the pathogenesis of hypertension. New Engl. J. Med. 356: 1966-78.

[42] Kaur, A. and Kochhar, A. 2014. Sensory and nutritional evaluation of value added product using potato flour for nutritional and health benefits. Internat. J. Med. Sci, 7 (1\&2): $1-6$.

[43] Pallavi, Y. V., Singh, A., Singh, K. K., Pandey and Awasthi, A. K. 2013. Genetic variability, estimation for various characters in pea (pisum sativum) for mollisol of uttarakhand. International Journal of Plant, Animal and Environmental Sciences, 2231-4490.

[44] Wani, S. A. and Kumar, P. 2016. Effect of incorporation levels of oat and green pea flour on the properties of an extruded product and their optimization. Acta Alimen, 45 (1): 28-35.

[45] Muhammad H. Alu'datt, Taha Rababah, Mohammad N. Alhamad, Khalil Ereifej, Sana Gammoh, Stan Kubow, and
Deia Tawalbeh 2017. Preparation of mayonnaise from extracted plant protein isolates of chickpea, broad bean and lupin flour: chemical, physiochemical, nutritional and therapeutic properties. J Food Sci Technol.; 54 (6): 13951405.

[46] Drakos, A., Doxastakis, G., and Kiosseoglou, V. (2007). Functional effects of lupin proteins in comminuted meat and emulsion gels. Food Chemistry 100, 650-655.

[47] Gulewicz, P., Martínez-Villaluenga, C., Frias, J., Ciesiołka, D., Gulewicz, K., and VidalValverde, C. 2008. Effect of germination on the protein fraction composition of different lupine seeds. Food Chemistry 107, 830-844.

[48] Shadan, M. R., Waghray, K. and Khoushabi, F. (2014). Formulation, Preparation and Evaluation of Low-Cost Extrude Products Based on Cereals and Pulses. Food and Nutrition Sciences, 5, 1333-134.

[49] Wani, I. A., Sogi, D. S., Wani, A. A. and Gill, B. S. 2013. Physico-chemical and functional properties of flours from Indian kidney bean (Phaseolus vulgaris L.) cultivars. Lebensm- Wiss Technol, 53: 278-284.

[50] Kaur, M. and Singh, N. 2005. Studies on functional, thermal and pasting properties of flours from different chickpea (Cicer arietinum L.) cultivars properties of different flours. Food Chemistry, 91: 403-411.

[51] Chandra, S. and Samsher. 2013. Assessment of functional properties of different flours African Journal of Agricultural Research, 8 (38): 4849-4852.

[52] Kohajdová, Z. Karovicová, J. M. and Croat, M. 2013. Rheological and qualitative characteristics of pea flour incorporated cracker biscuits J. Food Sci. Technol, 5 (1): 1117.

[53] Ettoumi, L Y. and Chibane, M. 2015. Some physicochemical and functional properties of pea, chickpea and lentil whole flours International Food Research Journal, 22 (3): 987-996. 